\title{
Regulation of Extracellular Collagenase Production in Achromobacter iophagus
}

\author{
By G. C. REID, F. T. ROBB AND D. R. WOODS \\ Department of Microbiology, Rhodes University, Grahamstown 6140, South Africa
}

(Received 29 March 1978; revised 28 June 1978)

\begin{abstract}
Achromobacter iophagus synthesized extracellular collagenase in a highly aerated peptone medium at the late-exponential and early-stationary phases of growth. Collagenase synthesis was subject to end-product repression and was repressed by various amino acids and ammonium ions. Glutamine caused severe repression of collagenase production. Collagenase synthesis was sensitive to catabolite repression by glucose and a number of carbon sources. Cyclic AMP, dibutyryl cyclic AMP and cyclic GMP did not relieve catabolite repression. Glucose and 2-deoxyglucose caused a severe transient repression. Although rifampicin and chloramphenicol immediately inhibited RNA and protein synthesis, respectively, they failed to inhibit collagenase production completely. No intracellular preformed collagenase was detected and collagenase production ceased when induced cells were washed and resuspended in buffer.
\end{abstract}

\section{INTRODUCTION}

Welton \& Woods $(1973,1975)$ described the isolation from hides of an aerobic, collagenolytic, Gram-negative Achromobacter iophagus strain which produces an inducible extracellular collagenase with the highest specific activity for a collagenase (Lecroisey et al., 1975). Keil-Dlouha et al. (1976) showed that collagenase is synthesized as the culture enters stationary phase and that it is induced by collagen and its high molecular weight fragments. Robbertse et al. (1978) reported the induction of collagenase by peptone but not by gelatin. Since peptone is used for the industrial production of collagenase by $A$. iophagus we have investigated the regulation of collagenase synthesis in a peptone medium. Although there are many reports of true exoprotein production by Gram-positive bacteria (Priest, 1977) there are few reports on the regulation of exoproteins in Gram-negative bacteria (Glenn, 1976), in contrast to numerous reports on periplasmic space proteins.

\section{METHODS}

All percentage compositions are $\mathrm{w} / \mathrm{v}$ and all nutrients were from Difco, unless otherwise stated.

Bacteria. The collagenolytic A. iophagus strain isolated from hides by Welton \& Woods (1973) was used. The strain was identified as A. iophagus using the seventh edition of Bergey's Manual of Determinative Bacteriology (Breed et al., 1957), but using the eighth edition (Buchanan \& Gibbons, 1974) it was found to be of uncertain taxonomic position.

Media and chemicals. The $A$. iophagus strain was maintained on the complex medium of Welton \& Woods (1973). The peptone medium was $2 \cdot 5 \%$ peptone in $0 \cdot 1 \mathrm{M}$-Tris/ $\mathrm{HCl}$ buffer $(\mathrm{pH} 7 \cdot 6)$ containing $0.4 \mathrm{M}-\mathrm{NaCl}$ and $2 \mathrm{~mm}^{-\mathrm{CaCl}_{2}}$. One drop of silicone anti-foaming agent was added per $100 \mathrm{ml}$ broth. The Casamino acids medium was $2.5 \%$ vitamin-free acid-hydrolysed casein in similar Tris/ $\mathrm{HCl}$ buffer. Amino acids, adenosine $3^{\prime}: 5^{\prime}$-cyclic monophosphoric acid (sodium salt) (cyclic AMP), dibutyryl cyclic AMP, guanosine $3^{\prime}: 5^{\prime}$-cyclic monophosphoric acid (sodium salt) (cyclic GMP) and 2-deoxy-D-glucose were obtained from Sigma. The various carbon sources were obtained from Merck.

Growth conditions and collagenase production. Samples $(10 \mathrm{ml})$ of overnight aerated A. iophagus cultures in 


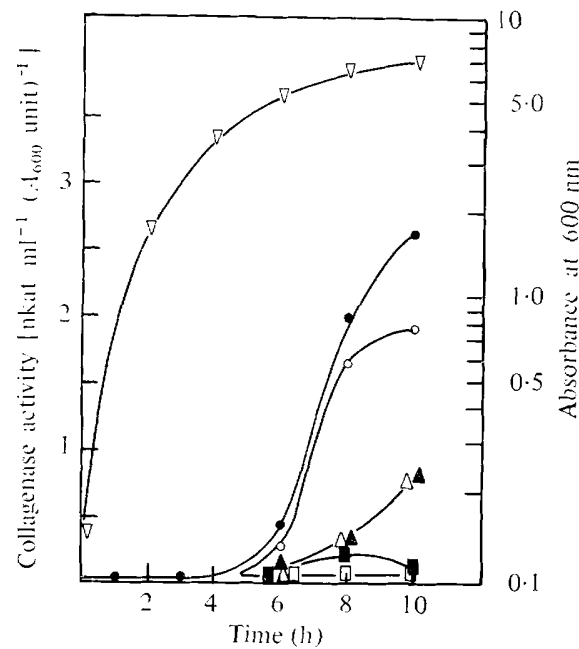

Fig. 1

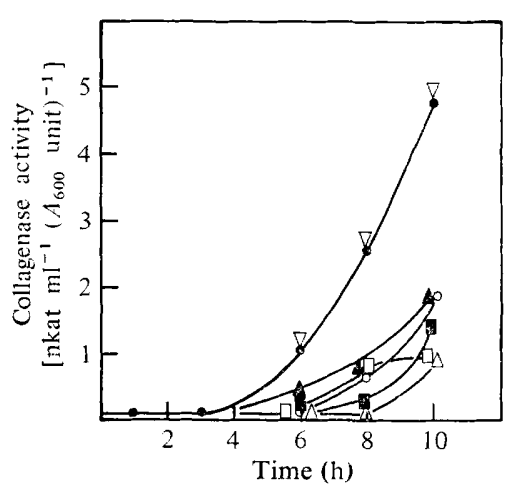

Fig. 2

Fig. 1. Effect of glucose and 2-deoxy-D-glucose on collagenase production in peptone medium. No additions (O);0.4\% glucose added at $2 \mathrm{~h}(\square), 4 \mathrm{~h}(\square)$ and $6 \mathrm{~h}(\mathrm{O}) ; 0.2 \%$ glucose added at $3.5 \mathrm{~h}(\Delta), 0.4 \%$ 2-deoxy-D-glucose added at $3.5 \mathrm{~h}(\triangle)$. Absorbance of control culture $(\nabla)$.

Fig. 2. Effect of cyclic nucleotides on glucose repression of collagenase production. Glucose and the cyclic nucleotides were added at $3.5 \mathrm{~h}$. No additions $(0) ; 0.2 \%$ glucose $(0) ; 0.2 \%$ glucose plus $5 \mathrm{mM}$-cyclic AMP $(\triangle) ; 0 \cdot 2 \%$ glucose plus $5 \mathrm{mM}$-dibutyryl cyclic AMP $(\boldsymbol{\square}) ; 0.2 \%$ glucose plus 5 mM-cyclic GMP $(\square) ; 5$ mM-AMP (A);2 mM-GMP ( $\nabla)$.

the Casamino acids medium were inoculated into $100 \mathrm{ml}$ peptone medium and incubated on an orbital shaker at $250 \mathrm{rev} . \mathrm{min}^{-1}$ at $30^{\circ} \mathrm{C}$ for $2.5 \mathrm{~h}$. Loosely fitting aluminium foil caps were used instead of bungs to facilitate aeration. The culture was then divided into $10 \mathrm{ml}$ aliquots and growth was followed turbidimetrically at $600 \mathrm{~nm}$. Supernatant fractions obtained by centrifugation of the cultures were assayed for collagenase at different times. Collagenase was assayed using the synthetic substrate phenylazobenzyloxycarbonyl-L-prolyl-L-leucyl-glycyl-L-prolyl-D-arginine (PZ-Pro-Leu-Gly-Pro-Arg) (Fluka, Buchs, Switzerland) by a modification of the method of Wünsch \& Heidrich (1963) in which the Tris/HCl buffer was used instead of veronal/acetate buffer to make up the substrate. Collagenolytic activity was expressed as nkat (ml supernatant $)^{-1}\left(A_{600} \text { unit }\right)^{-1}$, or as nkat $(\mathrm{ml} \text { supernatant })^{-1}$ in experiments where rifampicin or chloramphenicol were added.

Repression of collagenase synthesis. The effects of the addition, at different times, of various carbon sources, amino acids (Table 1), ammonium ions, antibiotics and cyclic nucleotides on collagenase production were investigated.

RNA and protein synthesis. RNA and protein synthesis were determined by the incorporation of $\left[{ }^{3} \mathrm{H}\right]$ uracil $\left(2 \mu \mathrm{g} \mathrm{ml}^{-1}, 0.4 \mu \mathrm{Ci} \mathrm{m}{ }^{-1}\right)$ and $\left[{ }^{14} \mathrm{Clleucine}\left(2 \mu \mathrm{g} \mathrm{ml}^{-1}, 0.4 \mu \mathrm{Ci} \mathrm{ml}{ }^{-1}\right)\right.$, respectively, into trichloroacetic acid (TCA)-precipitable material by the method of Eichenlaub \& Winkler (1974). Rifampicin and chloramphenicol were each added to exponential phase cells to give a final concentration of $300 \mu \mathrm{g} \mathrm{ml}^{-1}$.

Ultrasonic disintegration and toluene treatment of cells. In order to determine whether collagenase was preformed within the cell, $4 \mathrm{ml}$ samples of culture were disintegrated with a MSE ultrasonic disintegrator and their collagenase activity was then compared with the activity of untreated control samples. Cells were also treated with toluene to determine whether they would release preformed collagenase or become permeable to the substrate and indicate the presence of preformed collagenase: $0.2 \mathrm{ml}$ toluene was mixed with $0.5 \mathrm{ml}$ samples of culture and the collagenase activity was determined in the supernatant and in uncentrifuged samples.

\section{RESULTS}

Kinetics of collagenase production. Collagenase was produced in the peptone medium when the culture reached the late-exponential and early-stationary phases of growth (6 to $12 \mathrm{~h}$ ) and maximum yields were obtained after 10 to $12 \mathrm{~h}$ (Fig. 1). Production of collagenase was affected by aeration and optimum yields were only obtained under highly aerated conditions. 


\section{Table 1. Effect of various carbon sources, amino acids and ammonium ions on collagenase production}

Carbon sources were added at $0.2 \%$ and amino acids at $0.5 \%$. Additions were made to peptonegrown cultures $3.5 \mathrm{~h}$ after inoculation, and collagenase activity was assayed at 6 and $8 \mathrm{~h}$ after inoculation.

\begin{tabular}{|c|c|c|c|c|c|}
\hline \multirow[b]{2}{*}{ Addition } & \multicolumn{2}{|c|}{$\begin{array}{c}\text { Activity } \\
(\% \text { of control })\end{array}$} & \multirow[b]{2}{*}{ Addition } & \multicolumn{2}{|c|}{$\begin{array}{c}\text { Activity } \\
(\% \text { of control })\end{array}$} \\
\hline & $6 \mathrm{~h}$ & $8 \mathrm{~h}$ & & $6 \mathrm{~h}$ & $8 \mathrm{~h}$ \\
\hline None & 100 & 100 & Casamino acids $(1 \%)$ & 1 & 4 \\
\hline Glucose & 0 & 9 & Casamino acids $(0.5 \%)$ & 3 & 47 \\
\hline Fructose & 5 & 17 & Glutamine & 3 & 5 \\
\hline Sucrose & 0 & 18 & L-Proline & 38 & 28 \\
\hline$D(+)$-Mannose & 0 & 19 & Histidine. $\mathrm{HCl}$ & 17 & 31 \\
\hline Mannitol & 10 & 22 & Glycine & 14 & 33 \\
\hline Maltose & 9 & 24 & Tryptophan & 53 & 49 \\
\hline Glycerol & 0 & 28 & Isoleucine & 100 & 60 \\
\hline Succinic acid ( $\mathrm{Na}_{2}$ salt $)$ & 24 & 28 & L-Hydroxyproline & 100 & 60 \\
\hline Pyruvic acid ( $\mathrm{Na}$ salt) & 8 & 38 & Leucine & 64 & 61 \\
\hline Arabinose & 50 & 63 & $\beta$-Alanine & 80 & 100 \\
\hline 2-Oxoglutaric acid & 80 & 70 & $\left(\mathrm{NH}_{4}\right)_{2} \mathrm{SO}_{4}(100 \mathrm{~mm}-\mathrm{N})$ & 65 & 100 \\
\hline Lactose & 70 & 100 & $\left(\mathrm{NH}_{4}\right)_{2} \mathrm{SO}_{4}(200 \mathrm{mM}-\mathrm{N})$ & 40 & 42 \\
\hline
\end{tabular}

Glucose repression of collagenase synthesis. Addition of $0.4 \%$ glucose to the peptone culture before $6 \mathrm{~h}$, the time at which collagenase production normally starts, completely inhibited the synthesis of collagenase (Fig. 1). The glucose analogue 2-deoxy-D-glucose at the same concentration $(0.4 \%)$ had a transient inhibitory effect on the production of collagenase when added at $3.5 \mathrm{~h}$ (Fig. 1). Addition of 2-deoxy-D-glucose at $2 \mathrm{~h}$, at concentrations of $0.2 \%$ and $0.4 \%$, also resulted in a transient inhibitory effect, with $0.4 \% 2$ deoxy-D-glucose causing more inhibition than $0.2 \%$ (results not shown). This transient effect was also observed with $0.2 \%$ glucose (Fig. 1) and $0.05 \%$ glucose had no effect on collagenase production. The addition of $0.4 \%$ glucose after $6 \mathrm{~h}$ caused a slight reduction in collagenase production. Various other carbon sources repressed the synthesis of collagenase (Table 1). Lactose, which the bacterium was unable to utilize (Welton \& Woods, 1973), caused little repression after $6 \mathrm{~h}$ and no repression after $8 \mathrm{~h}$.

Effect of cyclic nucleotides. Repression of collagenase synthesis by glucose was not relieved by 5 mM-cyclic AMP, 5 mm-dibutyryl cyclic AMP or 5 mM-cyclic GMP (Fig. 2). The addition of $5 \mathrm{~mm}$-cyclic AMP actually inhibited collagenase production whereas 2 mM-cyclic GMP had no effect (Fig. 2).

Effect of amino acids. Casamino acids $(0.5$ and $1 \%)$ and various individual amino acids $(0.5 \%)$ inhibited collagenase production (Table 1). Glutamine caused severe repression of collagenase synthesis but other amino acids inhibited collagenase production to a lesser extent. Ammonium ions ( 100 to $200 \mathrm{~mm}-\mathrm{N}$ ) also repressed collagenase synthesis.

Effect of antibiotics. The addition of $200 \mu \mathrm{g}$ rifampicin $\mathrm{ml}^{-1}$ and $500 \mu \mathrm{g}$ chloramphenicol $\mathrm{ml}^{-1}$ at $3 \mathrm{~h}$ prevented the production of collagenase (Fig. 3). When these antibiotics were added at $6 \mathrm{~h}$, collagenase production was not inhibited completely and significant increases in activity occurred. However the effect of $300 \mu \mathrm{g}$ rifampicin $\mathrm{ml}^{-1}$ and $300 \mu \mathrm{g}$ chloramphenicol $\mathrm{ml}^{-1}$ on the incorporation of $\left[{ }^{3} \mathrm{H}\right]$ uracil and $\left[{ }^{14} \mathrm{C}\right]$ leucine, respectively, into TCAprecipitable material when added at $6 \mathrm{~h}$ indicated that rifampicin inhibited RNA synthesis and chloramphenicol inhibited protein synthesis immediately (Fig. 4).

Collagenase assays and peptone inhibition. Cell-free peptone culture filtrates obtained after 6 and $8 \mathrm{~h}$ incubation were diluted in the Tris $/ \mathrm{HCl}$ buffer and in peptone medium, i.e. the Tris $/ \mathrm{HCl}$ buffer containing $2.5 \%$ peptone. The filtrates obtained at 6 and $8 \mathrm{~h}$ and diluted in the Tris $/ \mathrm{HCl}$ buffer showed 3- and 11 -fold higher collagenase activities, respectively, than 


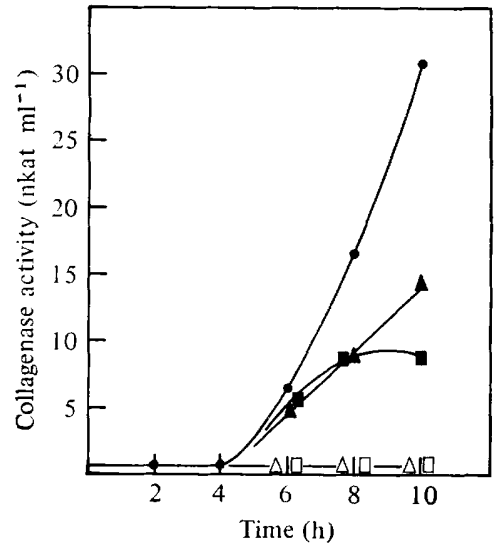

Fig. 3

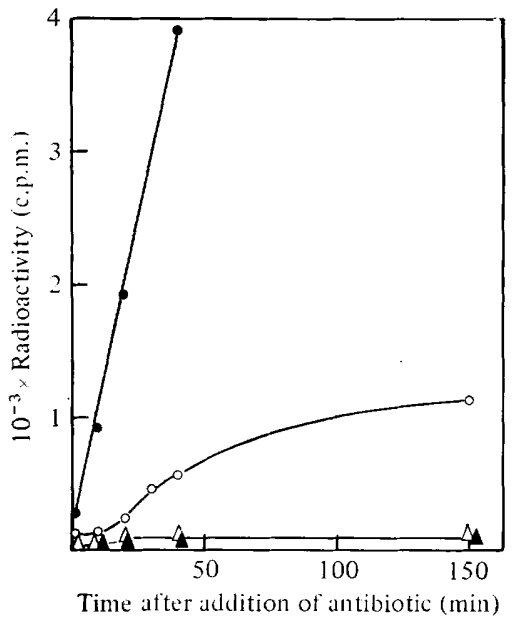

Fig. 4

Fig. 3. Effect of rifampicin and chloramphenicol on collagenase production. No additions (O) $200 \mu \mathrm{g}$ rifampicin $\mathrm{ml}^{-1}$ added at $3 \mathrm{~h}(\triangle)$ and $6 \mathrm{~h}(\Delta) ; 500 \mu \mathrm{g}$ chloramphenicol $\mathrm{ml}^{-1}$ added at $3 \mathrm{~h}$ $(\square)$ and $6 \mathrm{~h}(\boldsymbol{\square})$.

Fig. 4. Effects of rifampicin and chloramphenicol on the incorporation of $\left[{ }^{3} \mathrm{H}\right]$ uracil and $\left[{ }^{14} \mathrm{C}\right] \mathrm{leu}-$ cine, respectively, into TCA-precipitable material. $\left[{ }^{3} \mathrm{H}\right]$ Uracil incorporation: no additions $(\mathrm{O})$; $300 \mu \mathrm{g}$ rifampicin $\mathrm{ml}^{-1}$ added at $6 \mathrm{~h}(\triangle)$. $\left[{ }^{14} \mathrm{C}\right]$ Leucine incorporation: no additions $(\circlearrowleft) ; 300 \mu \mathrm{g}$ chloramphenicol $\mathrm{ml}^{-1}$ added at $6 \mathrm{~h}(\mathbf{\Delta})$.

Table 2. Effect of ultrasonic disintegration and toluene treatment on collagenase activity

\begin{tabular}{|c|c|c|c|c|c|}
\hline \multirow{4}{*}{$\begin{array}{l}\text { Age of } \\
\text { culture (h) }\end{array}$} & \multicolumn{5}{|c|}{ Collagenase activity (nkat $\mathrm{ml}^{-1}$ ) } \\
\hline & \multirow{2}{*}{\multicolumn{2}{|c|}{$\begin{array}{c}\text { Ultrasonic } \\
\text { disintegration }\end{array}$}} & \multicolumn{3}{|c|}{ Toluene treatment } \\
\hline & & & \multirow[b]{2}{*}{ Untreated } & \multirow{2}{*}{$\begin{array}{c}\text { Treated: } \\
\text { supernatant }\end{array}$} & \multirow{2}{*}{$\begin{array}{c}\text { Treated: } \\
\text { uncentrifuged }\end{array}$} \\
\hline & Untreated & Treated & & & \\
\hline 4 & $0 \cdot 58$ & $0 \cdot 58$ & $0 \cdot 47$ & 0.55 & 0.55 \\
\hline 6 & $9 \cdot 11$ & $7 \cdot 95$ & $3 \cdot 53$ & $2 \cdot 89$ & $2 \cdot 84$ \\
\hline 8 & & & $6 \cdot 46$ & $7 \cdot 20$ & $5 \cdot 79$ \\
\hline 10 & & & $10 \cdot 60$ & $8 \cdot 20$ & $7 \cdot 21$ \\
\hline
\end{tabular}

equivalent filtrates diluted in Tris $/ \mathrm{HCl}$ buffer plus peptone. The peptone therefore appeared to inhibit the collagenase. Furthermore the collagenase activity of a cell-free supernatant increased $2 \cdot 6$-fold over a $2 \mathrm{~h}$ period suggesting that degradation of an inhibitor of the enzyme occurred.

Ultrasonic disintegration and toluene treatment. Ultrasonic disintegration or toluene treatment of the cells did not result in an increase in collagenase activity (Table 2).

Release of collagenase by washed cells. Experiments were carried out to determine whether induced cells which were producing collagenase in the peptone medium would continue to release collagenase in buffer after washing. Washed induced cells did not produce collagenase in buffer.

\section{DISCUSSION}

The production of collagenase by $A$. iophagus requires a specific inducer and only occurs at the late-exponential and early-stationary phases of growth in highly aerated cultures. This pattern of exoenzyme synthesis in a complex medium is similar to protease, nuclease and cell wall-lytic enzyme production by Bacillus strains (Priest, 1977). The growth of cells 
to late-exponential phase and the precise time of collagenase synthesis, at $6 \mathrm{~h}$, facilitated studies of the regulation of enzyme formation.

In common with exo-protease synthesis by bacteria of a number of genera, including Bacillus, Sarcina and Arthrobacter, collagenase production is subject to control by endproduct repression (Glenn, 1976). Various amino acids and ammonium ions repressed collagenase production. The severe repression by glutamine suggests that the enzymes involved in glutamine metabolism may be implicated in the regulation of collagenase (Streicher et al., 1974; Friedrich \& Magasanik, 1977), possibly in similar roles to hose occupied by glutamine synthetase in the induction of histidase. Experiments are in progress to isolate glutamine auxotrophs and study the effects of the mutations on the regulation of collagenase. It is interesting that glycine, which constitutes one-third of all the amino acids in collagen, strongly repressed collagenase synthesis. Lecroisey et al. (1975) reported that histidine inhibited purified collagenase and part of the apparent repression caused by histidine may be due to the inactivation of the collagenase. Isoleucine and proline, which have been identified as the most common repressive amino acids in other bacteria (Glenn, 1976), also repressed collagenase synthesis but not as severely as glutamine.

In addition to end-product repression the synthesis of collagenase is subject to catabolite repression by a number of different growth substrates. However, the addition of exogenous cyclic AMP, dibutyryl cyclic AMP [which stimulates the synthesis of $\beta$-galactosidase in Caulobacter crescentus (Shapiro et al., 1972)] or cyclic GMP did not relieve catabolite repression. The failure of cyclic AMP to overcome the glucose effect has been reported for extracellular enzyme synthesis in Vibrio parahaemolyticus (Tanaka \& Iuchi, 1971), Pseudomonas maltophilia (Boethling, 1975), Pseudomonas lemoignei (Stinson \& Merrick, 1974), Staphylococcus aureus (Yoshikawa et al., 1974) and many Bacillus species (Priest, 1977). Cyclic AMP actually inhibited the synthesis of collagenase. A similar inhibitory effect of cyclic AMP was reported for the synthesis of extracellular 1,3- $\beta$-glucanase in a Streptomyces strain (Lilley et al., 1974). As well as inducing catabolite repression the addition of $0.2 \%$ glucose or $0.4 \% 2$-deoxy-D-glucose resulted in a severe transient repression similar to the transient repression observed with the lac operon in Escherichia coli (Tyler et al., 1967). Higher concentrations of glucose $(0.4 \%)$ resulted in a complete repression of collagenase synthesis. The isolation by Robbertse et al. (1978) of a colG mutant, which is insensitive to glucose but repressed by amino acids, and a col $A$ mutant, which is insensitive to glucose but requires amino acids, suggests that the glucose and amino acid effects are mediated differently.

Rifampicin and chloramphenicol added at $6 \mathrm{~h}$ failed to inhibit collagenase production completely and increases in activity occurred. Rifampicin inhibited RNA synthesis and chloramphenicol inhibited protein synthesis immediately. The increase in activity of the chloramphenicol culture could be due to the release of preformed enzyme. However this seems unlikely as ultrasonic disintegration or treatment of cells with toluene did not result in an increase in collagenase activity. Furthermore Keil-Dlouha et al. (1976) also reported that no zymogen or cell-accumulated enzyme is present during exponential growth. Some of the increase in activity with time could have been due to preformed collagenase reducing the concentration of an inhibitor (possibly inducer molecules) in the peptone culture. This would result in a decrease in the concentration of the inhibitor in the medium and an increase in collagenase activity. Because of this effect it is not possible to conclude whether exoenzyme synthesis is supported for a period in the absence of messenger synthesis, as was shown for protease secretion in P. maltophilia (Boethling, 1975). These results emphasize the care that must be taken when studying the regulation of inducible enzymes in complex media.

Induced cells which have been washed do not continue to synthesize collagenase in buffer. This may be due to the removal of the inducer. Alternatively the failure to continue synthesis of collagenase may be due to the absence of an energy source. Attempts are being made to 
isolate a constitutive mutant in order to study the control of induction of collagenase by the large inducer molecule. Synthesis of collagenase by $A$. iophagus provides an ideal model for studying the regulation of exoenzyme production which requires the specific induction by a large macromolecule such as collagen.

D. R.W. and G.C.R. acknowledge research grants from the South African Council for Scientific and Industrial Research.

\section{REFERENCES}

Boethling, R. S. (1975). Regulation of extracellular protease secretion in Pseudomonas maltophilia. Journal of Bacteriology 123, 954-961.

Breed, R. S., Murray, E. G. D. \& SMith, N. R. (editors) (1957). Bergey's Manual of Determinative Bacteriology, 7th edn. Baltimore: Williams and Wilkins.

Buchanan, R. E. \& Gibbons, N. E. (editors) (1974). Bergey's Manual of Determinative Bacteriology, 8th edn. Baltimore: Williams and Wilkins.

Eichenlaub, R. \& Winkler, U. (1974). Purification and mode of action of two bacteriocins produced by Serratia marcescens. Journal of General Microbiology 83, 83-94.

Friedrich, B. \& MaGasanik, B. (1977). Urease of Klebsiella aerogenes: control of its synthesis by glutamine synthetase. Journal of Bacteriology 131 , $446-452$.

GlenN, A. R. (1976). Production of extracellular proteins by bacteria. Annual Review of Microbiology 30, 41-62.

Keil-Dlouha, V., Misrahi, R. \& KeIL, B. (1976). The induction of collagenase and a neutral proteinase by their high molecular weight substrates in Achromobacter iophagus. Journal of Molecular Biology 107, 293-305.

Lecroisey, A., Keil-Dlouha, V., Woods, D. R., PERrIN, D. \& KeIL, B. (1975). Purification, stability and inhibition of the collagenase from Achromobacter iophagus. FEBS Letters 59, 167172.

Lilley, G., Rowley, B. I. \& Bull, A. T. (1974). Extracellular $\beta$-1,3-glucanase synthesis by continuous flow cultures of a thermophilic streptomycete. Journal of Applied Chemistry and Biotechnology 24, 677-686.

Priest, F. G. (1977). Extracellular enzyme synthesis in the genus Bacillus. Bacteriological Reviews 41, 711-753.

Robbertse, P. J., WoOds, D. R., ReAY, A. H. \& Rовв, F. T. (1978). Simple and sensitive pro- cedure for screening collagenolytic bacteria and the isolation of collagenase mutants. Journal of General Microbiology 106, 373-376.

Shapiro, L., Agabian-Keshishian, N., Hirsch, A. \& Rosen, O. M. (1972). Effect of dibutyryl $3^{\prime}: 5^{\prime}$-cyclic monophosphate on growth and differentiation in Caulobacter crescentus. Proceedings of the National Academy of Sciences of the United States of America 69, 1225-1229.

Stinson, M. W. \& Merrick, J. M. (1974). Extracellular enzyme secretion by Pseudomonas lemoignei. Journal of Bacteriology 119, 152-161.

Streicher, S. L., Shanmugam, K. T., Ausubel, F., Morandi, C. \& Goldberg, R. B. (1974). Regulation of nitrogen fixation in Klebsiella pneumoniae: evidence for a role of glutamine synthetase as a regulator of nitrogenase synthesis. Journal of Bacteriology 120, 815-821.

TANAKA, S. \& IUCHI, S. (1971). Induction and repression of an extracellular proteinase in Vibrio parahaemolyticus. Biken Journal 14, 81-96.

Tyler, B., LoOmis, W. F., JR \& MagasaniK, B. (1967). Transient repression of the lac operon. Journal of Bacteriology 94, 2001-2011.

Welton, R. L. \& Woods, D. R. (1973). Halotolerant collagenolytic activity of Achromobacter iophagus. Journal of General Microbiology 75, 191-196.

Welton, R. L. \& Woods, D. R. (1975). Collagenase production by Achromobacter iophagus. Biochimica et biophysica acta 384, 228-234.

WünsCH, E. \& HeIdrich, H. G. (1963). Zur quantitativen Bestimmung der Kollagenase. HoppeSeyler's Zeitschrift für physiologische Chemie 333, 149-151.

Yoshikawa, M., Matsuda, F., Naka, M., MuroFushi, E. \& Tsunematsu, Y. (1974). Pleiotropic alterations of activities of several toxins and enzymes in mutants of Staphylococcus aureus. Journal of Bacteriology 119, 117-122. 